\title{
PENGIMPLEMENTASIAN MEDIA PEMBELAJARAN BERBASIS MULTIMEDIA INTERAKTIF PADA MATA PELAJARAN MATEMATIKA DI SEKOLAH DASAR
}

\author{
Mila C. Paseleng \& Rizki Arfiyani \\ mila.paseleng@staff.uksw.edu \\ Fakultas Teknologi Informasi Universitas Kristen Satya Wacana - Salatiga
}

\begin{abstract}
ABSTRAK
Kurangnya minat siswa dalam mempelajari matematika disebabkan karena pendekatan pembelajaran yang digunakan guru masih konvensional sehingga menyebabkan siswa tidak tertarik untuk mempelajari matematika. Penelitian ini bertujuan untuk mengetahui bagaimana media pembelajaran berbasis multimedia interaktif dapat mempengaruhi minat belajar. Penelitian ini menggunakan desain quasi eksperimen nonequivalent control group. Hasil penelitian diperoleh peningkatan aspek minat belajar siswa pada mata pelajaran matematika yang ditunjukkan dengan rata-rata persentase setiap indikator pada kelas eksperimen yaitu indikator perhatian sebesar $83 \%$, indikator ketertarikan sebesar 75\%, dan indikator keterlibatan siswa sebesar 70\%, sedangkan pada kelas kontrol menunjukkan rata-rata presentse setiap indikator yaitu indikator perhatian sebesar $47 \%$, indikator ketertarikan sebesar $44 \%$, dan indikator keterlibatan sebesar 44\%. Dari hasil penelitian ini dapat disimpulkan bahwa media pembelajaran berbasis multimedia interaktif memberikan pengaruh positif terhadap pembentukan minat belajar siswa khususnya pada mata pelajaran.
\end{abstract}

Kata kunci: minat belajar, media pembelajaran, multimedia interaktif

\section{PENDAHULUAN}

Pelajaran matematika merupakan salah satu pelajaran utama yang diajarkan tidak hanya di sekolah dasar tapi di setiap jenjang pendidikan yang bertujuan untuk mengembangkan kemampuan berpikir siswa. Matematika memperkenalkan konsep, keterampilan dan strategi berpikir yang esensial dalam kehidupan sehari-hari, Belajar matematika merangsang rasa ingin tahu, mendorong kreativitas dan melengkapi siswa dengan keterampilan yang dibutuhkan dalam kehidupan di luar sekolah. Hal ini sejalan dengan yang dikatakan Mulyana (2004) bahwa matematika selain dapat memperluas cakrawala juga dapat mengembangkan kesadaran tentang nilai-nilai yang terdapat didalamnya yaitu nilai disiplin, keseimbangan, kreatif dan inovatif. Pemerintah menyadari akan pentingnya peran matematika dalam mewujudkan ketercapaian kompetensi inti dalam kurikulum 2013 maka pelajaran matematika untuk tingkat sekolah dasar diberi alokasi waktu minimal 5 jam/minggu untuk kelas 1 dan 6 jam/minggu untuk kelas selanjutnya (Kemendikbud, 2013). 
Pengimplemantasian Media Pembelajaran Berbasis Multimedia Interaktif pada Mata

Pelajaran Matematika di Sekolah Dasar (Mila C. Paseleng \& Rizki Arfiyani)

Alokasi waktu ini cukup besar dan kontennya sendiri dikembangkan dari pusat dengan harapan siswa akan memiliki penguasaan kompetensi yang baik dan merata.

Berdasarkan pengamatan proses belajar dan wawancara terhadap guru matematika serta beberapa siswa di SD Negeri Mrisen 2 Demak, diperoleh informasi bahwa matematika merupakan salah satu mata pelajaran yang dianggap sulit oleh siswa khususnya dalam mempelajari operasi perhitungan bilangan. Pengetahuan tentang operasi perhitungan bilangan ini adalah pengetahuan dasar yang harus dimiliki oleh siswa untuk dapat menguasai konsep matematika yang lebih kompleks. Anggapan ini mengakibatkan beberapa siswa menjadi malas dalam belajar matematika, beberapa siswa masih enggan untuk ikut berperan aktif pada saat pembelajaran berlangsung, minat mereka dalam mempelajari matematika tergolong rendah. Kesulitan pada matematika salah satunya disebabkan karena pembelajaran matematika kurang bermakna, siswa belum aktif terlibat dalam kegiatan pembelajaran, penggunaan media pembelajaran yang kurang efektiv sehingga pemahaman siswa tentang konsep matematika sangat lemah.

Menurut hasil survey IMSTEP-JICA (Development of Sciene And Mathematics Teaching for Primary and Second Education in Indonesia (IMSTEP) Japan International Cooperation Agency (JICA)) proses pembelajaran metematika guru umumnya terlalu berkonsentrasi pada latihan menyelesaikan soal. Dalam kegiatan pembelajaran, guru biasanya menjelaskan konsep secara informatif, sedangkan siswa selama kegiatan pembelajaran cenderung pasif. Siswa hanya mendengarkan, mencatat penjelasan, dan mengerjakan soal. Kondisi seperti ini membuat siswa kurang berminat untuk belajar.Penggunaan media pembelajaran meru akan salah satu upaya yang dilakukan oleh guru untuk memudahkan siswa dalam memahami pengetahuan yang diberikan, serta menumbuhkan ketertarikan dan minat siswa dalam belajar (Rusman dkk, 2012).

Ketersediaan perangkat komputer di sekolah kemudian mendorong dan memfasilitasi guru untuk mulai mengembangkan penggunaan media pembelajaran berbasis multimedia terutama yang bersifat interaktif. Milovanović dkk dalam penelitiannya memperlihatkan bahwa multimedia dapat memudahkan siswa dalam memahami pembelajaran dan mengimplementasikan pengetahuan dalam permasalahan atau latihan matematika (Milovanović et.al, 2013). Penelitian lainnya mengenai dampak penggunaan multimedia dalam pembelajaran matematika menunjukkan bahwa multimedia interaktif yang memanfaatkan gambar dan animasi game edukasi sangat efektif untuk memotivasi anak usia muda dalam belajar dan memperbaiki keterampilan belajar matematika mereka (Nusir et.al, 2012). Hasil dari dua penelitian ini membuktikan bahwa penggunaan media pembelajaran berbasis multimedia interaktiv dapat manjadikan pembelajaran matematika menjadi lebih mudah dan menarik sehingga bisa dimanfaatkan untuk memperbaiki minat belajar siswa pada pelajaran matematika. 
Berdasarkan permasalahan pada pembelajaran matematika di sekolah dan hasil penelitian sebelumnya tentang peran multimedia dalam pembelajaran matematika maka penelitian ini bertujuan untuk mengetahui bagaimana mengembangkan serta mengimplementasikan media pembelajaran interaktif berbasis multimedia yang dapat meningkatkan minat belajar matematika pada siswa SD.

\section{KAJIAN PUSTAKA}

\section{Kemampuan dan Pembelajaran Matematika}

Matematika berkenaan dengan ide, struktur-struktur, dan hubunganhubungannya yang diatur secara logik sehingga matematika berkaitan dengan konsep-konsep abstrak (Herman, 1988). Matematika membantu anak untuk memahami makna angka, pola dan bentuk yang mereka lihat di sekitarnya dan menunjukkan cara menangani data-data dalam dunia digital yang terus meningkat serta memberikan kontribusi penting pada kemampuan menyelesaikan masalah. Menurut Copley (2010), kemampuan dan pengetahuan matematika seorang anak dikonstruksi dari pengalaman dan pengamatan yang dilakukan terhadap lingkungan sekitar, akibatnya dimiliki banyak pengetahuan matematika yang bersifat intuisi. Dalam mengembangkan kemampuan matematika yang dimiliki tersebut seorang anak membutuhkan motivasi dan rasa nyaman yang akan menumbuhkan minat dan dorongan untuk mengatasi kesulitannya dalam mempelajari konsep matematika. Ini berarti bahwa dalam mengajarkan matematika akan sangat bermakna dan menarik jika pembelajarannya melibatkan pengalaman siswa melalui interaksi dengan media pembelajaran yang akan menvisualisasikan konsep dasar matematika sehingga lebih mudah untuk dipahami.

\section{Media Pembelajaran Interaktif Berbasis Multimedia}

Terdapat beberapa manfaat dari penggunaan media pembelajaran (Arsyad, 2006), yaitu: 1) memperjelas penyajian informasi yang diberikan oleh guru sehingga memperlancar proses pembelajaran. 2) Meningkatkan motivasi, interaksi langsung antara siswa dengan lingkungan, proses belajar mandiri, dan perhatian siswa. 3) Mengatasi keterbatasan indra, ruang dan waktu. 4) Memberikan kesamaan pengalaman kepada siswa tentang pristiwa-peristiwa dilingkungan mereka. Dengan manfaat yang dimiliki oleh media pembelajaran ini maka sangat tepat jika digunakan untuk mengatasi kesulitan yang muncul dalam pembelajaran matematika, sebagaimana yang dikemukakan oleh Siagian bahwa media pembelajaran berupa multimedia interaktif efektif dalam menyajikan pelajaran matematika dan sangat berpengaruh terhadap minat belajar matematika (Siagian, 2012).

Multimedia interaktif adalah suatu multimedia yang dilengkapi dengan alat pengontrol yang dapat dioperasikan oleh pengguna, sehingga pengguna dapat 
Pengimplemantasian Media Pembelajaran Berbasis Multimedia Interaktif pada Mata

Pelajaran Matematika di Sekolah Dasar (Mila C. Paseleng \& Rizki Arfiyani)

memilih apa yang dikehendaki untuk proses selanjutnya (Sucipto, 2010). Contoh multimedia interaktif adalah pembelajaran interaktif, aplikasi game, dll. Media pembelajaran interaktif berbasis multimedia digunakan untuk menyalurkan pesan (pengetahuan, keterampilan dan sikap) serta dapat merangsang pilihan, perasaan, perhatian dan kemauan siswa sehingga secara sengaja proses belajar terjadi, bertujuan dan terkendali.

Karakteristik media pembelajaran interaktif multimedia adalah sebagai berikut:

1.Memiliki lebih dari satu media yang konvergen, misalnya menggabungkan unsur audio dan visual.

2.Bersifat interaktif, dalam pengertian memiliki kemampuan untuk mengakomodasi respon pengguna.

3. Bersifat mandiri, dalam pengertian memberi kemudahan dan kelengkapan isi sedemikian rupa sehingga pengguna bisa menggunakan tanpa bimbingan orang lain.

Berdasarkan karakteristik tersebut maka sebuah media pembelajaran multimedia interaktif yang baik memiliki tampilan yang menarik karena dikemas dalam berbagai media, mudah digunakan serta bermanfaat bagi pembelajaran.

\section{Defenisi dan Ciri Minat Belajar}

Sujanto (2004) mendefenisikan "minat sebagai sesuatu pemusatan perhatian yang tidak sengaja yang terlahir dengan penuh kemauannya dan tergantung dari bakat dan lingkungannya". Slameto (2010) menyatakan bahwa "minat sebagai kecenderungan yang tetap untuk memperhatikan terus-menerus yang disertai rasa senang". Dari kedua defenisi tersebut dapat dikatakan bahwa minat belajar merupakan suatu dorongan yang dimiliki oleh seorang siswa untuk memperhatikan pembelajaran yang dihadapi dengan sukarela tanpa adanya paksaan karena ditunjukkan dengan perasaan senang dan hal itu terjadi terus menerus selama pembelajaran tersebut berlangsung. Djamarah (2008) mengungkapkan bahwa minat dapat diekpresikan anak didik melalui :

1. Pernyataan lebih menyukai sesuatu daripada yang lainnya,

2. Partisipasi aktif dalam suatu kegiatan yang diminati, serta

3. Memberikan perhatian yang lebih besar terhadap sesuatu yang diminatinya tanpa menghiraukan yang lain (fokus)

Dari beberapa pendapat para ahli di atas, dapat diketahui ciri-ciri/indikator adanya minat terhadap pelajaran antara lain: adanya perasaan senang dan ketertarikan siswa terhadap obyek yang diamati adanya perhatian siswa dalam pembelajaran, , dan keterlibatan siswa dalam proses pembelajaran. 


\section{METODE PENELITIAN}

Penelitian ini menggunakan pendekatan kuantitatif dengan desain quasi eksperimen nonequivalent control group desain untuk mengetahui bagaimana penggunaan media pembelajaran interaktif berbasis multimedia untuk meningkatkan minat siswa pada mata pelajaran matematika. Implementasi media pembelajaran yang dilakukan di dilakukan di SDN Mrisen 2 Demak dengan populasi siswa kelas 3 dan sampelnya adalah siswa kelas $3 a$ dan $3 b$. Menurutrekomendasi guru kelas $3 \mathrm{a}$ dan $3 \mathrm{~b}$ memiliki kemampuan yang tidak jauh beda, dari data sebelumnya juga menunjukkan bahwa kelas 3a dan $3 \mathrm{~b}$ memiliki kemampuan yang tidak jauh berbeda. Hal ini ditunjukkan oleh hasil pretest kedua kelas yang tidak jauh berbeda yaitu rata-rata nilai pretest kelas 3a lebih tinggi 0,87 dari siswa kelas 3b. Maka, kelas 3a merupakan kelas kontrol dan kelas 3b merupakan kelas eksperimen.

Pemberian treatment dilakukan secara berbeda pada kedua kelas. Kelas eksperimen akan menggunakan media interaktif yang dirancang dalam pembelajarannya, sedangkan kelas kontrol akan menggunakan pembelajaran yang masih sama dengan yang biasa dilakukan sebelumnya. Perlakuan yang berbeda ini bertujuan untuk mengetahui bagaimana dampak penerapan media pembelajaran interaktif terhadap mata pelajaran matematika.

\begin{tabular}{|c|c|c|}
\hline Q1 & X & Q2 \\
\hline Q3 & & Q4 \\
\hline
\end{tabular}

Gambar 1. Desain Nonequivalent control group (Sugiyono, 2013)

Keterangan:

Q1 : Hasil belajar siswa kelas eksperimen sebelum treatment

Q2 : Hasil belajar siswa kelas eksperimen setelah treatment

Q3 : Hasil belajar siswa kelas control sebelum treatment

Q4 : Hasil belajar siswa kelas control setelah treatment

Gambar 1 menunjukkan desain ekperimen yang digunakan. Peningkatan hasil belajar yang terjadi karena pengaruh minat belajar yang ditimbulkan oleh perlakuan (treatment) yang diberikan dapat dilihat dari selisih hasil belajar pada masingmasing kelas yaitu Q2-Q1 pada kelas eksperimen dan Q4-Q3 pada kelas control. Minat belajar siswa dalam hal ini diukur melalui observasi selama pembelajaran berlangsung.

Pengembangan media pembelajaran yang akan digunakan dalam kelas ekperimen dilakukan dengan analisis segala sesuatu yang dibutuhkan dalam 
Pengimplemantasian Media Pembelajaran Berbasis Multimedia Interaktif pada Mata

Pelajaran Matematika di Sekolah Dasar (Mila C. Paseleng \& Rizki Arfiyani)

pengembangan yaitu analisis tujuan dan karakteristik mata pelajaran, analisis sumber belajar, dan analisis karakteristik pembelajar. Selama proses pengembangan dilakukan perbaikan media, serta percobaan dan pengujian media. Pengembangan dan perbaikan media dengan mendesain, mengembangkan atau memodifikasi media sebelumnya sesuai dengan kemampuan dan karakteristik siswa .

Modifikasiyang dilakukan yaitu dengan memperbaiki isi materi pada media pembelajaran yang tadinya hanya berisi ringkasan materi yang hampir sama dengan buku, kemudian dikembangkan dan dikemas menjadi lebih ringkas dan menarikagar memudahkan siawa dalam memahami isi materi namun tidak bertentangan dengan apa yang ada di dalam kurikulum. Pengembangan media selanjutnya dengan memperbaiki tampilan pada game yang terdapat di dalam media yang awalnya kurang menarik dibuat menjadi lebih menarik, yang tadinya hanya terdapat satu level kemudian dimodifikasi atau dikembangkan dengan memberi tiga level tingkatan dimana dalam setiap levelnya memiliki kriteria tingkat kesulitan yang berbeda, namun tetap disesuaikan dengan kemampuan dan karakteristik siswa. Selanjutnya,dilakukan percobaan dengan cara menguji media pembelajaran yang sudah dibuat untuk dianalisis bersama-sama dengan pakar.

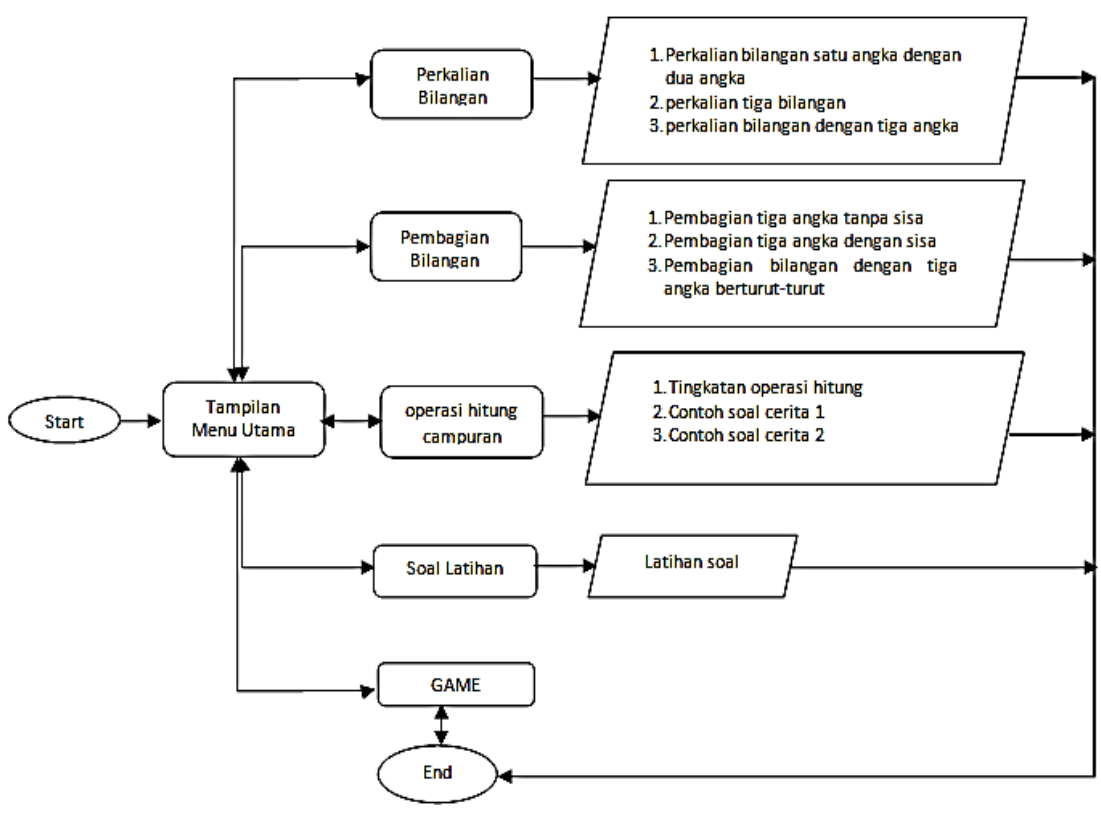

Gambar 2 Alur Media

Pada tahap percobaan terdapat 4 aspek yang ingin diketahui pada penelitian iniyaitumanfaat dan kegunaan media, tingkat kemudahan media, tingkat kemenarikan media, dan kesesuaian materi dengan silabus dan RPP sekolah. Jika 
pada percobaan pakar merasa aplikasi media belum sesuai dengan yang diinginkan dapat dilakukan perbaikan aplikasi dengan kembali ke tahapan pengembangan dan perbaikan media. Desain alur rancangan media pembelajaran yang akan diimplementasikan seperti yang ditunjukkan pada gambar 2 .

Gambar 2 merupakan gambaran alur media atau aktivitas yang dapat dilakukan oleh user yaitu guru dan siswa pada saat menggunakan media pembelajaran interaktif berbasis Multimedia. Terlihat pada saat pertama kali membuka media interaktif ini maka otomatis akan muncul halaman tampilan utama, pada tampilan utama terdapat beberapamenu. Menu yang pertama yaitu perkalian bilangan, jika dipilih maka akan menampilkan uraian isi materi. Dari menu pertama user dapat kembali ke tampilan utama untuk memilih menu-menu berikutnya yaitu menu ke 2 (pembagian bilangan) dan menu ke 3(operasi hitung campuran) pada kedua menu ini apabila dipilih juga akan menampilkan uraian isi materi. Selanjutnya dari tampilan utama user juga dapat memilih menu ke4 yaitu soal latihan yang apabila dipilih maka akan menampilkan soal-soal yang dapat di kerjakan oleh siswa, dengan tujuan untuk mengukur kemampuan dan sejauhmana mereka memahami materi. Dari tampilan utama juga bisa memilih menu yang ke 5 yaitu game, di dalam menu game terdiri dari tiga level. Tujuan dari game ini yaitu agar siswa tidak merasa bosan dan lebih tertarik dalam belajar matematika. Namun, di dalam game ini siswa tidak sepenuhnya hanya bermain, namun pada saat siswamemainkan game maka disitu juga terjadi proses belajar siswa.

Evaluasi dilakukan untuk mengetahui hasil dari penerapan media interaktif yang telah diterapkan dalam pembelajaran matematika. Evaluasi dilakukan dengan memberikan post-testpada siswa kelas kontrol dan eksperimen yangbertujuan untuk mengetahui kemampuan siswa dan sejauh mana mereka memahami materi yang sudah diberikan, serta sebagai pengukuran apakah ada perbedaan hasil belajar siswa pada kelas kontrol dan kelas eksperimensetelah diberi perlakuan berbeda. Evaluasi juga dilakukan dengan melakukan wawancara kepada salah seorang guru dan memberikan angket kepada siswa. Dari wawancara ini dapat diketahui tanggapan guru tentang media yang telah diterapkan, kesesuaian media dengan kebutuhan pembelajaran yang ada pada silabus dan RPP. Dari angket ini juga dapat diketahui tanggapan siswa tentang media interaktif yang telah dirancang dalam pembelajaran matematika, tingkat kemudahan dan ketertarikan media interaktif yang dirancang untuk siswa.

Instrumen pengumpulan data yang digunakan dalam penelitian yaitu observasi, angket dan wawancara. Observasi dilakukan pada kelas kontrol dan eksperimen dengan tujuan untuk mengetahui minat belajar siswa pada mata pelajaran matematika setelah diberikan perlakukan yang berbeda. Aspek yang diamati dari observasi minat siswa dalam belajar matematika dapat dilihat pada tabel tabel 1: 
Pengimplemantasian Media Pembelajaran Berbasis Multimedia Interaktif pada Mata

Pelajaran Matematika di Sekolah Dasar (Mila C. Paseleng \& Rizki Arfiyani)

Tabel 1Indikator minat belajar Siswa

\begin{tabular}{|l|l|}
\hline \multicolumn{1}{|c|}{ Indikator } & \multicolumn{1}{|c|}{ Sub indikator } \\
\hline Aspek perhatiaan & $\begin{array}{l}\text { Mengerjakan instruksi yang diberikan, tidak melakukan } \\
\text { pekerjaan lain diluar pembelajaran, tidak mengobrol dengan } \\
\text { teman. }\end{array}$ \\
\hline Aspek ketertarikan & $\begin{array}{l}\text { Semangat dalam belajar,merasa senang/tertarik, mudah } \\
\text { memahami, mengerjakan tugas yang diberikan guru, } \\
\text { berusaha unutk mendapat nilai yang bagus. }\end{array}$ \\
\hline $\begin{array}{l}\text { Aspek keterlibatan } \\
\text { siswa }\end{array}$ & $\begin{array}{l}\text { Berani mengemukakan pendapatnya sendiri, berani bertanya } \\
\text { apabila kurang jelas. }\end{array}$ \\
\hline
\end{tabular}

Untuk kualifikasi penilaian pada aspek minat terlihat pada tabel 2:

Tabel 2. Kualifikasi penilaian aspek minat

\begin{tabular}{|c|c|c|}
\hline Interval & Kritetia & Nilai Akhir \\
\hline $76 \%-100 \%$ & Sangat baik & A \\
\hline $51 \%-75 \%$ & Baik & B \\
\hline $26 \%-50 \%$ & Cukup & C \\
\hline $0 \%-25 \%$ & Kurang & D \\
\hline
\end{tabular}

Instrumen angket/kuesioner ditujukan kepada siswa, untuk mengetahui kualitas dan manfaat media pembelajaran berdasarkan tanggapan siswa terhadap media interaktif yang telah dirancang dalam pembelajaran matematika. Angket diberikan kepada siswa setelah dilakukan treatment. Angket siswa disusun menggunakan skala likert yang masing-masing kategori jawaban diberi skala skor 1-5yaitu : Sangat Baik $(\mathrm{SB})=5$, Baik $(B)=4$, Cukup $(\mathrm{C})=3$, Kurang $(\mathrm{K})=2$, Sangat Kurang $(\mathrm{SK})=1$ dan dianalisi berdasarkan persentase jumlah siswa pada setiap kategori jawaban. Untuk indikator yang digunakan pada angket siswa dapat dilihat pada tabel 2. Untuk menghitung persentase masing-masing kategori jawaban dari angket siswa digunakan rumus sebagai berikut (Hermawan, 1992):

$P=F / N \times 100 \%$

P : Persentase data

$\mathrm{F}:$ Frekuensi/jumlah data

$\mathrm{N}$ : Jumlah responden 
Tabel 3. Indikator kualitas media pembelajaran

\begin{tabular}{|l|l|}
\hline \multicolumn{1}{|c|}{ Indikator } & \multicolumn{1}{|c|}{ Penjelasan } \\
\hline Tingkat kesulitan media & $\begin{array}{l}\text { Apakah media interaktif yang telah dibuat sulit } \\
\text { untuk digunakan. }\end{array}$ \\
\hline Tingkat kemenarikan media & $\begin{array}{l}\text { Apakah tampilan pada media interaktif sudah } \\
\text { menarik. }\end{array}$ \\
\hline $\begin{array}{l}\text { Tingkat kesenangan siswa pada } \\
\text { media }\end{array}$ & $\begin{array}{l}\text { Apakah siswa senang menggunakan media } \\
\text { interaktif yang dirancang pada pembelajaran } \\
\text { matematika. }\end{array}$ \\
\hline $\begin{array}{l}\text { Tingkat kemudahan memahami } \\
\text { materi pada media }\end{array}$ & $\begin{array}{l}\text { Apakan materi pada media interaktif mudah untuk } \\
\text { dipahami siswa. }\end{array}$ \\
\hline $\begin{array}{l}\text { Tingkat pemahaman materi pada } \\
\text { pokok bahasan perhitungan } \\
\text { bilangan }\end{array}$ & $\begin{array}{l}\text { Apakan siswa lebih memahami materi pada pokok } \\
\text { bahasan dengan bantuan media interaktif. }\end{array}$ \\
\hline $\begin{array}{l}\text { Tingkat kejenuhan siswa dalam } \\
\text { belajar }\end{array}$ & $\begin{array}{l}\text { Apakah siswa merasa jenuh/bosan dalam belajar } \\
\text { dengan bantuan media interaktif yang telah } \\
\text { dirancang pada matapelajaran matematika. }\end{array}$ \\
\hline
\end{tabular}

Untuk memudahkan penafsiran terhadap persentase yang telah diolah maka digunakan parameter penafsiran berikut:

$$
\begin{array}{ll}
0,0 \% & =\text { Tidak ada } \\
0,1 \%-24,9 \% & =\text { Sebagian kecil } \\
25 \%-49,9 \% & =\text { Hampir setengah } \\
50 \% & =\text { Setengah } \\
50,1 \%-74,9 \% & =\text { Sebagian besar } \\
75 \%-99,9 \% & =\text { Pada umumnya } \\
100 \% & =\text { Seluruhnya }
\end{array}
$$

Selanjutnya adalah wawancara yang ditujukan kepada salah seorang guru dengan mengajukan pertanyaan-pertanyaan mengenaipenggunaan media pembelajaran matematika yang dipakai sebelumnya dan bentuk/jenis bagaimana, pendapat tentang penggunaan media pembelajaran interaktif berbasis multimedia yang sudah diterapkan, dan kendala-kendala yang ditemui oleh guru saat menggunakan media pembelajaran berbasis multimedia ini. Tujuan dari wawancara ini untuk mengetahui tanggapan atau pendapat guru setelah penerapan media pembelajaran interaktif berbasis multimedia yang sudah diterapkan pada mata pelajaran matematika di SD Negeri Mrisen 2. Dari keseluruhan data-data yang diperoleh pada penelitian ini akan dianalisis untuk menjawab rumusan masalah yang ada. Pengolahan data dilakukan dengan menganalisis data hasil observasi, wawancara, dan angket. 
Pengimplemantasian Media Pembelajaran Berbasis Multimedia Interaktif pada Mata

Pelajaran Matematika di Sekolah Dasar (Mila C. Paseleng \& Rizki Arfiyani)

\section{HASIL DAN PEMBAHASAN}

Media pembelajaran berbasis multimedia interaktif ini terdiri dari 3 komponen utama yaitu materi, latihan dan game. Ketiga komponen ini dapati digunakan guru sebagai alat bantu dalam proses pembelajaran dan bisa juga digunakan siswa untuk mempermudah dalam belajar mandiri dan memahami materi terutama mata pelajaran matematika. Pada setiap tampilan komponen, siswa sebagai pengguna dapat melakukan interaksi dengan system pada aplikasi media pembelajaran yang dilengkapi dengan tampilan yang menarik dan bahasa yang sederhana dalam bentuk gambar dan audio. Ini akan memudahkan siswa dalam memproses informasi dan memdapatkan suasana yang menyenangkan dalam dari bermain games. Kondisi tersebut akan menggerakkan motivasi instrinsik dan memunculkan minat belajar siswa terhadap objek pada media. Ini sejalan dengan pendapat Lui, Toprac, and Yuen (2009) bahwa faktor yang berkontribusi terhadap motivasi intrinsic adalah kondisi menyenangkan atau permainan, pemrosesan informasi dan control diri atau tindakan sukarela tanpa paksaan (Frey \& Sutton, 2010).

Siswa sebagai pengguna memiliki control penuh untuk memilih materi yang akan diperlajari, memilih waktu untuk mengerjakan tes dan menentukan target skor dalam bermain game. Dengan demikian kemandirian siswa dalam belajar dan kebebasan untuk menentukan cara penggunaan media bagi guru maupun siswa dapat terfasilitasi.

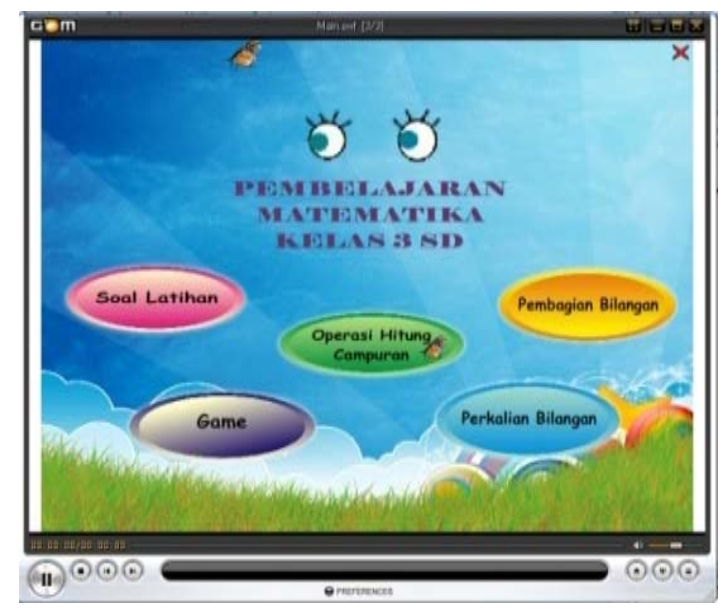

Gambar 3 Tampilan utama

Gambar 3 menunjukkan tampilan utama media pembelajaran matematika kelas 3 SD. Tampilan ini terdiri dari tiga menuinti yang sudah dikelompokkan yaitu menu materi, soal latihan, dan game. Tujuan dibuat beberapa menu yaitu untuk memudahkan siswa dalam mengoperasikan dan memahami isi menu yang ada pada media interaktif. Menu materi terbagi menjadi tiga sub menu yang dapat dipilih oleh 
siswa yaitu perkalian bilangan, pembagian bilangan, dan operasi hitung campur. Apabila siswa memilih salah satu submenu materi misalnya perkalian bilangan maka media interaktif akan menampilkan isi materi yang terlihat pada gambar 5 .
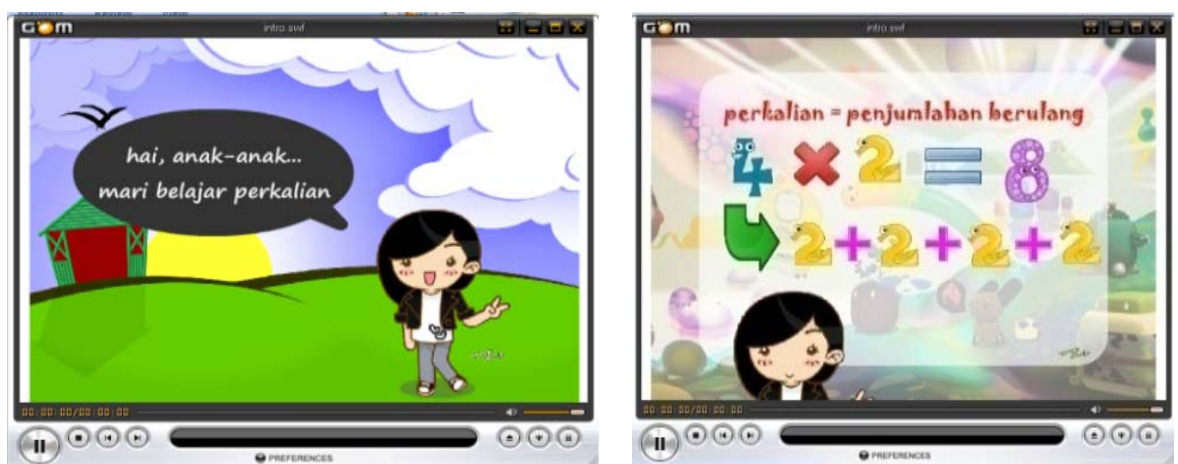

Gambar 4 Tampilan isi materi

Gambar 4 Tampilan isi materi Isi dari sub menu perkalian bilangan yang akan ditampilkan pada media pembelajaran interaktif ini terdiri dari deskripsi perkalian, perkalian dua angka dengan bilangan satu angka, perkalian tiga bilangan, dan perkalian bilangan dengan tiga angka. Hal serupa juga akan ditampilkan media apabila siswa memilih menu materi yang lain yaitu pembagian bilangan dan operasi hitung campur. Isi materi dikemas seperti pada gambar 4 karena menyesuaikan karakteristikdari siswanya, dengan tujuan agar menarik perhatian siswa dan memudahkan siswa dalam memahami isi materi.

Menu materi ini disajikan secara interaktif melalui instruksi-instruksi berupa ajakan dari tokoh animasi yang muncul pada setiap transisi materi. Selain itu konsep operasi matematika juga dijelaskan dengan menunjukkan langkah-langkah operasi yang menggunakan gambar grafis dengan warna menarik dan audio pada tokoh animasi untuk membantu menjelaskan makna dari konsep tersebut. Dengan kemasan seperti ini maka konsep operasi bilangan pada matematika dapat dipelajari oleh siswa dengan mudah dan mereka pun menjadi lebih tertarik karena adanya tampilan audio visual sehingga dapat membentuk minat belajar.

Menu selanjutnya yang dapat dipilih siswa yaitu menu latihan soal dan game. Latihan soal dan game ini dapat digunakan siswa untuk latihan menerapkan konsep matematika yang sudah mereka pelajari tanpa adanya tekanan dari guru dan beban bahwa matematika itu sulit. Konsep game menimbulkan rasa penasaran dan menyenangkan bagi siswa untuk menyelesaikan tantangan yang ada didalamnya sehingga tanpa sadar siswa sebenarnya sudah berlatih untuk menerapkan pengetahuan matematikanya. Apabila siswa memilih menu latihan soal maka media interaktif akan menampilkan soal latihan seperti yang terlihat pada gambar 6 . 
Pengimplemantasian Media Pembelajaran Berbasis Multimedia Interaktif pada Mata Pelajaran Matematika di Sekolah Dasar (Mila C. Paseleng \& Rizki Arfiyani)

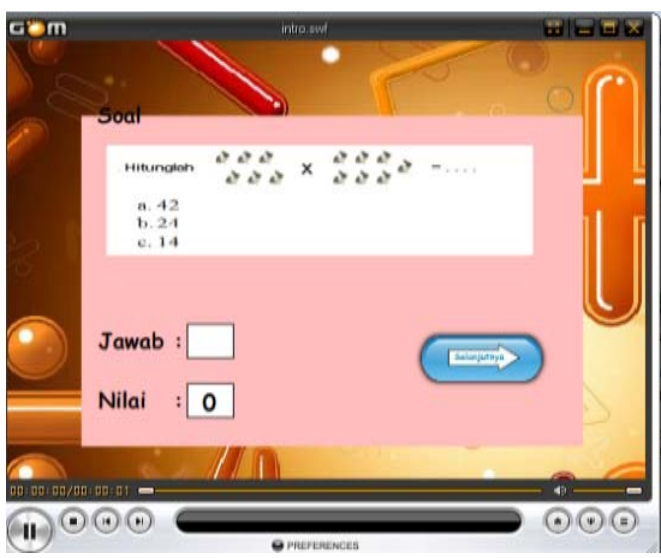

Gambar 5 Tampilan pada menu soal latihan

Menu soal latihan terdapat soal-soal yang dapat dikerjakan siswa untuk mengukur kemampuannya sendiri. Soal latihan yang ada pada media interaktif dibuat dengan merujuk pada indikator pencapaian yang terdapat dalam SKKD. Soal yang dikerjakan berjumlah 10 nomor dari 20 soal yang sudah diatur untuk tampil secara acak. Soal yang tampil pada media pembelajaran interaktif yang dibuka siswa satu dengan siswa yang lain pada waktu yang sama akan berbeda.Hal ini bertujuan untuk memperkecil kemungkinan siswa untuk bekerjasama dengan siswa yang lain, sehingga kemampuan siswa dalam memahami materi dapat terlihat.Menu yang terakhir yaitu gameinteraktif yang dapat dimainkan oleh siswa. Apabila siswa memmbuka memilih menu game, maka media interaktif akan menampilkan isi dari game seperti yang terlihat pada gambar 6 .

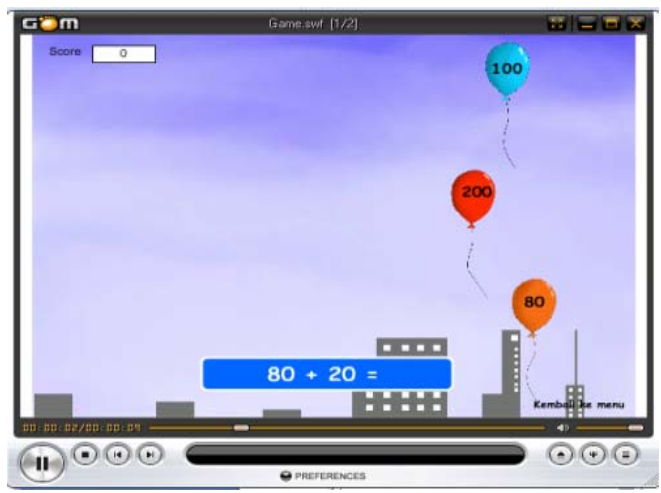

Gambar 6 Tampilan game 
Game yang ada pada media interaktif dirancang dalam pembelajaran dengan menyesuaikan karakteristik mata pelajaran matematika yang identik dengan berhitung dan disesuaikan dengan karakteristik siswanya. Game yang dirancang terdiri dari tiga level dengan tingkat kesulitan yang berbeda. Isi dari gamepada level pertama yaitu berisi soal penjumlahan dan pengurangan yang diberi tingkatan mudah.Aturan yang ada pada game yaitu, apabila pada level pertama skor siswa bisa mencapai lebih dari 60 maka dapat melanjutkan ke level selanjutnya, sedangkan apabila kurang dari 60 maka akan mengulang kembali pada level tersebut, aturan ini berlaku untuk semua level pada game yang ada dalam mediainteraktif yang telah dirancang. Pada level kedua game berisi soal-soal perkalian dan pembagian dengan tingkatan sedang, sedangkan pada level ketiga berisi soal-soal campuran dari penjumlahan, pengurangan, perkalian dan pembagian dengan tingkatan sulit. Game yang ada pada media ini bertujuan agar siswa tidak bosan dan lebih tertarik dalam belajar matematika.

Sebelum digunakan media pembelajran interaktif ini diujicoba oleh guru untuk melihat kesesuainya dengan kebutuhan pembelajaran matematika. Hasil ujicoba kepada guru ini diperoleh melalui wawancara yang mencakup 4 aspek yaitu: manfaat dan kegunaan media, kemudahan media, kemenarikan media, dan kesesuaian materi dengan SKKD. Hasil analisis dari tanggapan guru pada saat percobaan media memberikan hasil bahwa media pembelajaran ini bermanfaat dan berguna untuk membantu proses belajar siswa secara mandiri, media pembelajaran ini juga mudah untuk digunakan, serta mampu menarik perhatian siswa pada proses pembelajaran, materi yang ada di dalam mediajuga sudah sesuai dengan tujuan indikator pencapaian pada SKKD yang ada di sekolah. Hal-hal yang mendukung tanggapan guru tersebut yaitu guru merasa termotivasi dengan melihat media pembelajaran interaktif ini, karena melihat media-media yang digunakan guru sebelumnya hanya sebatas lidi/korek api dan batu kecil yang dirasa kurang menarik dan masih konvensional. Sehingga dapat disimpulkan bahwa media pembelajaran interaktif berbasis multimedia ini dapat dijadikan alat bantu guru dalam proses pembelajaran matematika dan dapat dijadikan bahan latihan siswa untuk belajar secara mandiri.

Dari pelaksanaan proses pembelajaran diperoleh beberapa hasil analisa data. Analisa data yang pertama adalah data dari observasi pada penilaian aspek minat belajar siswa. Data dari observasi diperoleh dengan menggunakan cheklist dari penilaian aspek minat yang terdiri dari 3 indikator yaitu perhatian, ketertarikan, dan keterlibatan siswa. Data yang diperoleh pada saat observasi minat siswa diolah untuk mengetahui persentase minat belajar siswa pada kelas kontrol dan eksperimen. 
Pengimplemantasian Media Pembelajaran Berbasis Multimedia Interaktif pada Mata

Pelajaran Matematika di Sekolah Dasar (Mila C. Paseleng \& Rizki Arfiyani)

Tabel 5 Minat belajar Siswa

\begin{tabular}{|l|c|c|}
\hline \multicolumn{1}{|c|}{ Indikator } & Kontol & Eksperimen \\
\hline Perhatian & $\mathbf{4 7 , 3 \%}$ & $\mathbf{8 2 , 7 \%}$ \\
\hline Ketertarikan & $\mathbf{4 4 , 3 \%}$ & $\mathbf{7 5 , 0 \%}$ \\
\hline Keterlibatan & $\mathbf{4 4 , 0 \%}$ & $\mathbf{6 9 , 7 \%}$ \\
\hline
\end{tabular}

Tabel 5 menunjukkan hasil rata-rata persentase minat belajar siswa pada kelas kontrol dan eksperimen. Dari tiga aspek minat yaitu perhatian, ketertarikan, dan keterlibatan siswa menunjukkan hasil rerata persentase pada kelas control semuanya berada pada kategori cukup dan jumlahnya rata-rata dibawah $50 \%$. Kondisi ini sangat jauh berbeda dengan yang terjadi di kelas eksperimen yang mana semua indicator berada pada kategori baik dan sangat baik dengan rata-rata jumlah persentase mendekati bahkan lebih dari 70\%. Ini menunjukkan bahwa minat siswa di kelas ekperimen dengan adanya penggunaan multimedia interaktif jauh lebih baik dari siswa di kelas control. Media interaktif yang telah dirancang memberi kesan positif, dimana saat menggunakan media interaktif siswa terkesan seperti sedang bermain padahal sebenarnya siswa juga berfikir dalam memahami materi dan berusaha menyelesaikan soal yang ada pada media hanya saja hal itu tidak disadari oleh siswa. Inilah yang membuat siswa tertarik untuk belajar .

Peningkatan hasil belajar juga terjadi pada kelas eksperimen sejalan dengan peningkatan minat belajar siswa. Hal ini dilihat dari hasil post testyang diberikan kepada siswa di kelas eksperimen dankelas kontrol. Untuk mengetahui seberapa besar peningkatan hasil belajar siswa dari pre test dan post tes pada kelas kontrol dan eksperimen digunakan perhitungangainternormalisasi dengan menggunakan rumus (Meltzer, 2002):

$$
(g)=\frac{(S \text { post })-(\text { S Pre })}{100 \%-(\text { S nre })}
$$

Keterangan:

(g) = Peningkatan hasil belajar siswa

S post $=$ Nilai rata-rata post test

$\mathrm{S}$ pre $=$ Nilai rata-rata pre test

$100 \%=$ Nilai maksimum

Adapun klasifikasi nilai $(g)$ adalah sebagai berikut:

$(g) \geq 0,70$ Peningkatan hasil belajar siswa tinggi

$0,30<(g) \leq 0,70$ Peningkatan hasil belajar siswa sedang

$(g) \leq 0,30$ Peningkatan hasil belajar siswa rendah. 
Hasil dari perhitungan gain ternormalisasi dari kelas kontrol dan eksperimen dapat dilihat sebagai berikut:

Tabel 6 Hasil Perhitungan Gain

\begin{tabular}{|l|c|c|c|c|c|}
\hline \multicolumn{1}{|c|}{ Kelas } & $\begin{array}{c}\text { Pre } \\
\text { Test }\end{array}$ & $\begin{array}{c}\text { Post } \\
\text { Test }\end{array}$ & Selisih & Gain (G) & Keterangan \\
\hline Kontrol & 51,31 & 77,06 & 25,75 & 0,528856 & Sedang \\
\hline Eksperimen & 50,44 & 87,56 & 38,37 & 0,780037 & Tinggi \\
\hline
\end{tabular}

Tabel 6 menunjukkan hasil perhitungan gain pada kelas kontrol dan eksperimen. Dari data nilai pretest pada kelas kontrol dan eksperimen yaitu 51,31 dan 50,44 yang berarti kedua kelas memiliki kemampuan awal yang hampir sama, setelah diberikan treatment dengan memberikanposttestdiperoleh perbedaan nilai yang singnifikan yaitu kelas kontrol sebesar 77,06 dengan selisih 25,75 dan kelas eksperimen sebesar 87,56 dengan selisih 38,37. Berdasarkan data nilai pretest dan posttest, diperoleh nilai gain $(G)$ ternormalisasi kelas eksperimen sebesar 0,780037 dengan kategori tinggi, sedangkan pada kelas kontrol sebesar 0,528856 dengan kategori sedang. Hal ini menunjukkan bahwa peningkatan hasil belajar di kelas eksperimen lebih tinggi dari kelas kontrol walaupun kedua kelas mengalami peningkatan.

Melalui interaksi dan aktivitas yang disajikan oleh media pembelajaran yang digunakan, siswa memperoleh kemudahan dalam memahami konsep dan dapat berlatih menerapkan konsep matematika tersebut melalui game yang tersedia. Pembelajaran dengan media ini juga dapat dilakukan secara mandiri oleh siswa dan secara berulang-ulang sehingga penguasaan mereka mengenai konsep matematika tersebut pun menjadi lebih baik. Hal ini yang kemudian berdampak pada hasil belajarnya.

Hasil analisa tanggapan guru dan siswa untuk menunjukkan bahwa media pembelajaran interaktif ini sangat membantu guru dalam proses pembelajaran, mampu menarik minat dan perhatian siswa, serta memudahkan siswa untuk memahami materi saat belajar mandiri. Wawancara kepada seorang guru, dari wawancara memberikan hasil bahwa guru memiliki tanggapan yang positif mengenai penggunaan media pembelajaran interaktif berbasis multimedia sebagai alat bantu guru pada saat mengajar, sekaligus membuat siswa tidak mudah bosan pada saat proses pembelajaran berlangsung dan menarik perhatian siswa untuk tetap fokus saat pembelajaran. Media pembelajaran interaktif berbasis multimedia ini memiliki tujuan yang baik yaitu mempermudah siswa dalam belajar mandiri khususnya pada mata pelajaran matematika yang selama ini dianggap susah oleh siswa, serta dengan media ini siswa menjadi lebih tertarik untuk belajar matematika. 
Pengimplemantasian Media Pembelajaran Berbasis Multimedia Interaktif pada Mata Pelajaran Matematika di Sekolah Dasar (Mila C. Paseleng \& Rizki Arfiyani)

Selanjutnya untuk mengetahui tanggapan siswa terhadap media interaktif berbasis multimeia dengan menggunakan angket yang diberikan pada kelas eksperimen yaitu sebanyak 16 responden dan terdapat 6 pertanyaan yang harus dijawab oleh siswa kelas eksperimen. Hasil analisa data angket siswa terlihat pada tabel berikut:

Tabel 7. Hasil Analisa Angket Siswa

\begin{tabular}{|l|c|c|c|c|}
\hline \multicolumn{1}{|c|}{ Indikator } & $\begin{array}{c}\text { Jumlah } \\
\text { Responde } \\
\text { n Per } \\
\text { Skala }\end{array}$ & $\begin{array}{c}\text { Rata- } \\
\text { rata } \\
\text { Skala }\end{array}$ & \% & $\begin{array}{c}\text { Keteranga } \\
\text { n }\end{array}$ \\
\hline 1. Tingkat kesulitan media & 67 & 4,19 & $68,8 \%$ & Mudah \\
\hline $\begin{array}{l}\text { 2. Tingkat kemenarikan media } \\
\text { 3. Tingkat kesenangan siswa pada } \\
\text { media }\end{array}$ & 73 & 4,56 & $62,5 \%$ & $\begin{array}{c}\text { Sangat } \\
\text { Menarik }\end{array}$ \\
\hline $\begin{array}{l}\text { 4. Tingkat kemudahan memahami } \\
\text { materi pada media }\end{array}$ & 64 & 4 & $75,0 \%$ & Mudah \\
\hline $\begin{array}{l}\text { 5. Tingkat pemahaman materi } \\
\text { pada pokok bahasan } \\
\text { perhitungan perkalian dan } \\
\text { pembagian }\end{array}$ & 61 & 3,81 & $56,3 \%$ & \begin{tabular}{c} 
Memahami \\
\hline $\begin{array}{l}\text { 6. Tingkat kejenuhan siswa dalam } \\
\text { belajar }\end{array}$
\end{tabular} \\
\hline
\end{tabular}

Penjelasan dari data tabel 7 yaitu menunjukkan pada indikator tingkat kesulitan media, menunjukkan bahwa sebagian besar siswa pada kelas eksperimen mempunyai asumsi bahwa media interaktif ini mudah untuk digunakan. Pada indikator tingkat kemenarikan media, menunjukkan bahwa sebagian besar siswa mempunyai asumsi bahwa media interaktif ini sangat menarik.

Pada indikator tingkat kesenangan siswa pada media, menunjukkan bahwa sebagian besar siswa mempunyai asumsi bahwa media interaktif ini menyenangkan. Pada indikator tingkat kemudahan dalam memahami materi pada media, menunjukkan hasil bahwa pada umumnya siswa kelas eksperimen mempunyai asumsi materi di dalam media interaktif ini dapat dipahami dengan mudah. Indikator tingkat pemahaman materi pada pokok bahasan perhitungan bilangan perkalian dan pembagian, menunjukkan hasil bahwa sebagian besar siswa kelas eksperimen mempunyai asumsi bahwa dengan media interaktif ini siswa dapat 
memahami materi pada mate pelajaran matematika khususnya pokok bahasan perhitungan bilangan perkalian dan pembagian. Terakhir pada indikator tingkat kejenuhan siswa dalam belajar menggunakan media interaktif, menunjukkan hasil bahwa sebagian siswa kelas eksperimen mempunyai asumsi bahwa belajar matematika dengan bantuan media interaktif ini tidak membuat siswa merasa jenuh/bosan.

Dari hasil analisa keseluruhan angket siswa ini menunjukkan bahwa sebagian besar siswa kelas eksperimen pada SDN Mrisen 2 mempunyai tanggapan positif terhadap penerapan media interaktif yang telah dirancang dalam pembelajaran matematika. Hal ini terjadi karena media interaktif ini lebih menarik perhatian dan minat siswa dibanding dengan media-media yang sudah dipakai sebelumnya (lidi/korek api). Berbagai kelebihan yang dimiliki media pembelajaran interaktif berbasis multimedia ini sangat memungkinkan siswa untuk terlibat aktif dalam kegiatan belajar mengajar di dalam kelas, menarik perhatian dan minat siswa dalam belajar, serta mampu meningkatkan hasil belajar siswa. Dengan demikian, dari keseluruhan data hasil penelitian yang telah diperoleh dapat disimpulkan bahwa dengan penerapan media pembelajaran interaktif berbasis multimedia di SDN Mrisen 2 mampu meningkatkan minat belajar siswa pada mata pelajaran matematika.

\section{SIMPULAN DAN SARAN}

Media pembelajaran yang dibuat interaktif berbasis multimedia dapat meningkatkan minat belajar siswa dalam mempelajari operasi perkalian dan pembagian pada mata pelajaran matematika di sekolah dasar karena memberikan pengalaman bermakna melalui tampilan menarik dan kegiatan menyenangkan melalui permainan (game). Minat siswa dalam pembelajaran yang menggunakan media tersebut termasuk dalam kategori sangat baik pada aspek perhatian siswa terhadap pembelajaran dengan persentase $82,7 \%$ dan $75 \%$ pada aspek ketertarikan siswa, sementara itu aspek keterlibatan siswa dalam pembelajaran pada kategori baik dengan persentase $69,7 \%$. Kondisi ini sangat jauh berbeda jika dibandingkan dengan kelas control, yang mana dalam semua aspek minat persentase siswa berada dibawah $50 \%$.

Minat belajar siswa yang sangat baik ini kemuadian sejalan dengan capaian hasil berlajar siswa yang lebih tinggi pada kelas ekperimen disbanding kelas control. Selain itu tanggapan siswa juga menunjukkan bahwa media pembelajran interaktif berbasis multimedia tersebut memiliki tampilan yang menarik, mudah digunakan dan memudahkan mereka dalam memahami pelajaran sehingga dapat dikatakan bahwa media ini dapat membantu pembelajaran matematika pada pokok bahasan operasi pekalian dan pembagian bilangan. 
Pengimplemantasian Media Pembelajaran Berbasis Multimedia Interaktif pada Mata

Pelajaran Matematika di Sekolah Dasar (Mila C. Paseleng \& Rizki Arfiyani)

Saran pengembangan yang dapat diberikan untuk penelitian yang akan datang diharapkan guru tidak hanya sebagai pengajar, tetapi juga sebagai motivator yang dapat membangkitkan minat dan perhatian siswa untuk belajar. Media yang digunakakan lebih dikembangkan agar mampu menarik perhatian siswa, sehingga proses belajar mengajar akan lebih menyenangkan. Untuk penerapan media pembelajan interaktif berbasis multimedia sebaiknya dilakukan tidak hanya pada satu sekolah saja. Untuk gameinteraktif dapat dikembangkan lagi dengan variasi yang lebih menarik dan tidak membosankan, namun tetap menyesuaikan karakterisktik mata pelajaran dan karakter siswanya.

\section{DAFTAR PUSTAKA}

Arsyad, Azhar. (2006). Media Pembelajaran. Jakarta: PT Raja Grafindo Persada.

Copley, Juanita. 2010. The Young Child and Mathematics, $2^{\text {nd }}$ edition. Virginia: National Council of Teachers of Mathematics. [Online]. https://www.naeyc.org/store/files/store/TOC/167.pdf . (17 Mei 2014)

Djamarah, Syaiful Bahri. (2008). Psikologi Belajar. Jakarta : PT. Rineka Cipta.

Frey, Barbara \& Sutton, Jane. 2010. A Model for Developing Multimedia Learning Projects. MERLOT Journal of Online Learning and Teaching. Vol.6 No.2, June: 491-507. [Online]. http://jolt.merlot.org/vol6no2/frey_0610.pdf (5 Juli 2014).

Hudojo, Herman. (1988). Mengajar Belajar Matematika. Jakarta : Proyek Pengembangan Lembaga Pendidikan Tenaga Kependidikan. Dirjendikti.

Kemendikbud. 2012. Dokumen Kurikulum 2013. Kementrian Pendidikan dan Kebudayaan .

Meltzer, D.E. (2002). "The Relationship between Mathematics preparation and Conceptual Learning Gain in Physics: a Possible Hidden Variable in Diagnostic Pretest Scores". Am.J.Phys. 70 (2), 1259-1267. [Online]. Tersedia:http://physicseducation.net/docs/Addendum_on_normalized_gain. pdf. Diakses tanggal 26-11-2014 jam 10.14

Milovanović, Marina et.al. 2013. Aplication of Interactive Multimedia Tools in Teaching Mathematics-Examples of Lessons From Geometry. TOJET: Turkish Online Jurnal of Educational Technology. January 2013, Vol.12, issue 1: 19-31. [online]. www.tojet.net. (20 Juni 2014).

Mulyana, Rahmat. 2004. Mengartikulasikan Pendidikan Nilai. Bandung: Alfabeta.

Nusir et.all. 2012. Studying The Impact Of Using Multimedia Interactive Programs At Children Ability To Learn Basic Math Skills. Acta Didactica Napocensia. 5(2):17-31.[Online]. Tersedia http://dppd.ubbcluj.ro/adn/article_5_2_3.pdf(1 Juni 2014). 
Rusman, dkk. 2012. Pembelajaran Berbasis Teknologi Informasi Dan Komunikasi. Jakarta : Rajawali Pres

Slameto. 2010. Belajar dan Faktor-Faktor yang Mempengaruhinya. Jakarta: Rineka Cipta.

Sucipto, 2010. Penulisan Naskah Pembelajaran Multimedia Interaktif Berbantuan Komputer (Multimedia). Makalah. Yogyakarta: Balai Teknologi Komunikasi Pendidikan (BTKP).

Siagian, Roida, E.V. (2012, Agustus). Pengaruh Minat dan Kebiasaan Belajar Siswa Terhadap Prestasi Belajar Matematika. Jurnal Formatif. 2(2):122-131. ISSN: 2088-351X

Sugiyono. 2013. Metode Penelitian Pendidikan : Pendekatan Kualitatif, Kuantitatif dan R \& D. Bandung: Alfabeta

Warsito, Hermawan. 1992. Pengantar Metodologi Penelitian. Jakarta: Gramedia Pustaka Utama. 